\title{
High sodium food consumption pattern among Malaysian population
}

\author{
Mohamad Hasnan Ahmad ${ }^{1 *}$, Cheong Siew Man ${ }^{1}$, Fatimah Othman ${ }^{1}$, Feng J. He², Ruhaya Salleh', \\ Noor Safiza Mohammad Noor ${ }^{3}$, Wan Nur Khairunnisa Wan Kozil ${ }^{1}$, Graham MacGregor ${ }^{2}$ and Tahir Aris ${ }^{1}$
}

\begin{abstract}
Background: Sodium is an essential mineral needed by the human body that must be obtained from food. An excess intake, however, can lead to many diseases. As food is the main source of sodium, this study aims to provide information on high sodium food consumption patterns in the Malaysian adult population.

Methods: The Malaysian Community Salt Study (MyCoSS) was a nationwide cross-sectional study, conducted between October 2017 and March 2018. A multistage complex sample was applied to select a nationally representative sample of respondents aged 18 years and above. Face to face interview by a validated Food Frequency Questionnaire (FFQ) comprising 104 food items was used to gain information on high sodium food consumption patterns.
\end{abstract}

Results: A total of 1047 respondents were involved in this study, with 1032 (98.6\%) answering the FFQ. From the number, $54.1 \%$ exceed the recommendation of sodium intake $<2000 \mathrm{mg} /$ day by FFQ assessment. The results also demonstrated that fried vegetables (86.4\%) were the most common high sodium food consumed, followed by bread (85.9\%) and omelet (80.3\%). In urban areas, bread was the most common while fried vegetables took the lead in rural areas. By sex, bread was most commonly eaten by males and fried vegetables by females. The results also found that kolok mee/kampua mee contributed the highest sodium, $256.5 \mathrm{mg} /$ day in $9.0 \%$ adult population, followed by soy sauce $248.1 \mathrm{mg} /$ day in $33.2 \%$ adult population, and curry noodles $164.2 \mathrm{mg} /$ day in $18.5 \%$ adult population.

Conclusion: Fried vegetables, bread, and soy sauce were the main source of sodium consumption among adult. Reducing the amount of sodium added to these foods should be the top priority to reduce population sodium intake and thereby prevent sodium-related diseases in Malaysia.

Keywords: High sodium food, Sodium consumption, Salt consumption, Population study, Malaysia, MyCoSS

\section{Background}

Sodium is an essential mineral needed by the human body that must be obtained from food. The role of sodium is to maintain electrolyte and water balance in the human body. It is also important in nerve and muscle function [1]. However, high consumption of sodium can

\footnotetext{
* Correspondence: hasnan.ahmad@moh.gov.my; mha.hasnan@gmail.com.my ${ }^{1}$ Institute for Public Health, National Institutes of Health, Ministry of Health Malaysia, Setia Alam, Selangor, Malaysia

Full list of author information is available at the end of the article
}

lead to non-communicable diseases (NCDs) especially cardiovascular disease [2]. A recent study also suggests that salt or sodium intake is a potential risk factor for obesity, another major concern in public health [3].

In Malaysia, the prevalence rates of diseases associated with high sodium intake are high. For example, the overall prevalence of hypertension (known and undiagnosed) among adults of 18 years and above in Malaysia in 2015 was $30.3 \%$. Meanwhile, the prevalence of obesity in the same age group was $17.7 \%$ [4]. There is no sign of 
decline in these diseases which prompts an urgent need to find comprehensive and effective prevention strategies.

Based on compelling evidence, the best strategy to help prevent diseases related to high sodium consumption is to limit dietary intake of sodium [5]. The World Health Organization (WHO) recommends a reduction to below $90 \mathrm{mmol}(<5 \mathrm{~g}$ salt) per day or $<2000 \mathrm{mg} /$ day sodium in the adult general population [6]. The Recommended Nutrient Intake (RNI) 2017 for Malaysia suggests a sodium requirement of $1500 \mathrm{mg} /$ day for adults 19 years and above [7].

By knowing the sodium requirement and foods with high in sodium, the individual can easily plan for their daily food intake by avoiding high-sodium foods. At the same time, the public health sector or related agencies can plan for effective intervention by understanding the pattern of high sodium food consumption in the population. Therefore, this study aims to provide baseline information on high sodium food consumption patterns in the Malaysian population.

\section{Methods}

\section{Study design and study population}

Data were taken from the Malaysian Community Salt Survey (MyCoSS), a nationwide cross-sectional study conducted between October 2017 and March 2018. The target population was respondents resided in the noninstitutional living quarters. Those staying in institutional residents such as hotel, hostels, hospitals, and prisons were excluded from the survey. Pregnant women, those who began diuretic therapy in the last 2 weeks, having kidney disease and any condition that limit their ability to collect 24-h urine were also excluded from this study. Ethical approval was obtained from the Medical Research Ethics Committee (MREC), Ministry of Health, and Queen Mary (University of London) Research Ethics Committee, UK. Signed informed consent form was obtained from each respondent before the interview and collection of urine samples.

\section{Sample size}

The sample size was calculated using a formula for estimating population prevalence. Sampling was designed to cover both urban and rural areas for every state in Malaysia. Calculations were done on all objectives as listed, and the biggest sample size was on the knowledge on the effect of high salt on health. We applied the findings of the previous salt study among the health workers in Malaysia (MySalt 2015) [8]. With the prevalence on knowledge on the effect of high salt on health of $6 \%$, confidence level of 95\%, estimated design effect of 1.5 , the optimum sample size for a stratum was 520 respondents. The sample size was then inflated $25 \%$ to cover for non-responses; hence, the sample size for each stratum was 650 respondents, estimated sample size was 1300 respondents.

\section{Food frequency questionnaire (FFQ)}

The Food Frequency Questionnaire (FFQ) consisting of 104 food items in 11 food groups was used to gain information on high sodium food consumption pattern. This FFQ has been used in the Malaysian Adult Nutrition Survey (MANS) 2014 with some modification and selection of high sodium food by the expert in nutrition [9]. Ten experts in nutrition applied several findings and discussed before finalizing all 104 food items to include in this FFQ. Respondents were asked in detail about each food item in a face-to-face interview by trained research assistants. Respondents answered all 104 food items in terms of frequency of intake either on a daily, weekly, or monthly basis and the number of servings they consumed during each time they ate the food. If the respondent did not consume the food on a monthly basis, they answered " 0 " in the per/month column.

\section{Data analysis}

The data were analyzed using IBM SPSS version 23 for Windows (SPSS Inc., Chicago, IL, USA). Sample weight was calculated by determining the base or design weight and adjusted for study non-responses. The sampled unit weight represented the probability of it being selected into the sample. The final weight used in the analysis was the post-stratification weight referring to the existing Malaysian population information provided by DOSM. Since this study applied a complex sampling design, the analysis was conducted accordingly with 95\% confidence interval. For FFQ, the conversion of food frequency to the amount of sodium in food intake was carried out using the following formula:

Amount of sodium (g) per day = frequency of intake (convert per day) $\times$ serving size $\times$ total number of servings $\times$ weight (in gram) of food in one serving $\times$ amount of sodium in $1 \mathrm{~g}$ of the food.

Descriptive statistics were used for describing the characteristics of the respondent and patterns of high sodium food consumption.

\section{Results}

A total of 1047 respondents were involved in this study making a response rate of $80.5 \%$. About 1032 respondents $(98.6 \%)$ completed the FFQ. Majority respondents aged 55 to 64 years old and there were more women (59.1\%) involved in this study compared to men (40.9\%). More respondents were from rural areas (58.5\%) compared to urban areas (41.5\%) (Table 1). About $54.1 \%$ of adults were found to exceed the sodium intake recommendation of $<2000 \mathrm{mg} /$ day by FFQ assessment. Our 
Table 1 Sociodemographic characteristics of respondent ( $N=$ 1032 respondents)

\begin{tabular}{|c|c|c|}
\hline Characteristics & Count & Percentage (\%) \\
\hline \multicolumn{3}{|l|}{ Age group (years old) } \\
\hline $18-24$ & 77 & 7.5 \\
\hline $25-34$ & 152 & 14.7 \\
\hline $35-44$ & 175 & 17.0 \\
\hline $45-54$ & 210 & 20.3 \\
\hline $55-64$ & 241 & 23.4 \\
\hline 65 and above & 177 & 17.2 \\
\hline \multicolumn{3}{|l|}{ Sex } \\
\hline Men & 422 & 40.9 \\
\hline Women & 610 & 59.1 \\
\hline \multicolumn{3}{|l|}{ Strata } \\
\hline Urban & 428 & 41.5 \\
\hline Rural & 604 & 58.5 \\
\hline \multicolumn{3}{|l|}{ State } \\
\hline Johor & 119 & 11.5 \\
\hline Kedah & 104 & 10.1 \\
\hline Kelantan & 75 & 7.3 \\
\hline Melaka & 36 & 3.5 \\
\hline Negeri Sembilan & 47 & 4.6 \\
\hline Pahang & 70 & 6.8 \\
\hline Pulau Pinang & 40 & 3.9 \\
\hline Perak & 90 & 8.7 \\
\hline Perlis & 27 & 2.6 \\
\hline Selangor & 103 & 10.0 \\
\hline Terengganu & 32 & 3.1 \\
\hline Sabah/Labuan & 139 & 13.5 \\
\hline Sarawak & 114 & 11.0 \\
\hline WP Kuala Lumpur/WP Putrajaya & 36 & 3.5 \\
\hline
\end{tabular}

study also found that fried vegetables, white/wholemeal bread and omelet were the most preferred high sodium food which was consumed by more than $80 \%$ of the Malaysian population as shown in Table 2. These top three foods remain in their rank when the analysis focused on the strata level (Table 3) and sex (Table 4). There was a difference in the urban area when white/wholemeal bread took the first position, the same as in male (Tables 3 and 4).

Mee kolok or kampua mee and light soy sauce contributed the highest sodium consumption in individuals with median consumption of $256.5 \mathrm{mg} /$ day and 248.1 $\mathrm{mg} /$ day respectively. However, the percentage of individuals who consumed these two food items was only $9.0 \%$ and $33.2 \%$, respectively (Table 5 ). Those who consumed $\geq 2000 \mathrm{mg}$ sodium per day were found to have a higher intake of fried vegetable, roti canai/roti telur, omelet, fried rice, and chicken curry compared to those who consumed less than $2000 \mathrm{mg}$ sodium per day according to 24-h urinary sodium analysis (Table 6).

\section{Discussion}

This nationwide survey showed that the top five high sodium foods most frequently consumed by Malaysian adults were fried vegetables, white bread/wholemeal bread, omelet, fried chicken with spices and fried rice. Generally, the most popular fried vegetables in Malaysia is stir-fried like spinach [10]. The findings are almost similar to national data on food consumption statistics among Malaysians, where about $80 \%$ of the Malaysian adults reported to consume white bread/wholemeal bread [11]. However, as the study focused on high sodium food, further comparisons cannot be done with Malaysian food consumption statistics database.

Prepared or home cooked food, such as fried vegetable, omelet, fried chicken, and fried rice, are believed to contribute the highest sodium intake in Malaysia based on the high prevalence of consumption. Data from

Table 2 Top 10 high sodium food most consumed by Malaysian adults ( $N=1032$ respondents)

\begin{tabular}{llllll}
\hline No. & Food items & $\begin{array}{l}\text { Unweighted } \\
\text { count }\end{array}$ & $\begin{array}{l}\text { Estimated } \\
\text { population }\end{array}$ & $\begin{array}{l}\text { Population consumed } \\
\text { \% }(\mathbf{9 5 \%} \mathbf{C l})\end{array}$ & $\begin{array}{l}\text { mg sodium (per day) } \\
\text { median (IQR) }\end{array}$ \\
\hline 1 & Fried vegetable & 870 & $16,775,456$ & $86.4(83.2,89.0)$ & $101.8(44.1,264.3)$ \\
2 & White/whole meal bread & 823 & $16,674,062$ & $85.9(83.1,88.2)$ & $59.3(29.6,118.6)$ \\
3 & Omelet & 796 & $15,586,616$ & $80.3(76.5,83.5)$ & $71.8(35.9,215.3)$ \\
4 & Fried chicken with spices & 713 & $14,034,531$ & $72.3(67.9,76.2)$ & $62.5(29.2,125.0)$ \\
5 & Fried rice & 683 & $13,609,154$ & $70.1(65.8,74.0)$ & $95.4(44.5,190.8)$ \\
6 & Nasi Lemak (set) & 622 & $13,021,095$ & $67.0(61.7,72.0)$ & $88.0(58.7,251.5)$ \\
7 & Roti canai/roti telur & 613 & $12,623,157$ & $65.0(60.7,69.1)$ & $99.3(66.2,283.7)$ \\
8 & Fried meehoon & 624 & $11,963,462$ & $61.6(56.8,66.2)$ & $53.7(26.9,115.1)$ \\
10 & Fried noodle & 626 & $11,914,301$ & $61.3(56.0,66.5)$ & $82.8(41.4,177.4)$ \\
\hline
\end{tabular}


Table 3 Top 10 high sodium food most consumed by Malaysian adults by strata

\begin{tabular}{|c|c|c|c|c|c|}
\hline \multirow[t]{2}{*}{ Food items } & \multicolumn{2}{|l|}{ Urban $(n=428)$} & \multirow[t]{2}{*}{ Food items } & \multicolumn{2}{|l|}{ Rural $(n=604)$} \\
\hline & $\begin{array}{l}\text { Population consumed, } \\
\%(95 \% \mathrm{Cl})\end{array}$ & $\begin{array}{l}\text { mg sodium (per day), } \\
\text { median (IQR) }\end{array}$ & & $\begin{array}{l}\text { Population consumed, } \\
\%(95 \% \mathrm{Cl})\end{array}$ & $\begin{array}{l}\text { mg sodium (per day), } \\
\text { median (IQR) }\end{array}$ \\
\hline $\begin{array}{l}\text { White/whole } \\
\text { meal bread }\end{array}$ & $88.9(85.4,91.6)$ & $59.28(29.6,133.4)$ & Fried vegetable & $82.8(77.9,86.8)$ & $88.1(33.0,231.3)$ \\
\hline Fried vegetable & $87.4(83.3,90.6)$ & $132.2(44.1,264.3)$ & $\begin{array}{l}\text { White/whole } \\
\text { meal bread }\end{array}$ & $75.5(71.4,79.2)$ & $31.1(13.8,88.9)$ \\
\hline Omelet & $81.7(76.9,85.8)$ & $71.8(33.5,215.3)$ & Omelet & $75.2(71.2,78.9)$ & $98.3(33.5,215.3)$ \\
\hline $\begin{array}{l}\text { Fried chicken } \\
\text { with spices }\end{array}$ & $72.5(67.0,77.4)$ & $62.5(29.2,125.0)$ & $\begin{array}{l}\text { Fried chicken } \\
\text { with spices }\end{array}$ & $71.3(65.6,76.5)$ & $62.5(29.2,125.0)$ \\
\hline Fried rice & $71.5(66.2,76.3)$ & $95.4(44.5,190.8)$ & Fried rice & $65.1(59.1,70.7)$ & $95.4(44.5,190.8)$ \\
\hline Nasi Lemak (set) & $69.5(62.9,75.5)$ & $88.0(44.0,192.8)$ & Nasi Lemak (set) & $58.6(51.3,65.5)$ & $88.0(44.0,251.5)$ \\
\hline $\begin{array}{l}\text { Roti canai/roti } \\
\text { telur }\end{array}$ & $65.8(60.5,70.8)$ & $99.3(66.2,283.7)$ & $\begin{array}{l}\text { Roti canai/roti } \\
\text { telur }\end{array}$ & $62.2(55.5,68.4)$ & $99.3(33.1,141.9)$ \\
\hline Fried meehoon & $61.8(55.6,67.7)$ & $53.7(26.9,115.1)$ & Fried meehoon & $60.9(55.9,65.7)$ & $53.7(26.9,115.1)$ \\
\hline Fried noodle & $61.7(54.7,68.2)$ & $82.8(41.4,177.4)$ & Fried noodle & $60.2(55.4,64.9)$ & $82.8(41.4,177.4)$ \\
\hline Chicken curry & $57.7(51.3,63.7)$ & $9.7(4.5,19.3)$ & Chicken curry & $56.5(51.1,61.7)$ & $9.0(4.5,19.3)$ \\
\hline
\end{tabular}

the International Study of Macro-and Micro-Nutrients (INTERMAP) study in China found that most dietary sodium came from salt added during preparing or cooking [12]. The same study reported that in developed countries, such as Japan, UK, and USA, most of the sodium came from processed foods.

The pattern of food preference was almost similar in urban or rural area and in men or women. However, in urban area and in men, white/wholemeal bread was more preferred compared to fried vegetables. A review paper from the Dublin Institute of Technology regarding food consumption trends and drivers also reported that urbanization was the main factor or drive to the high intake of processed food such as bread [13]. A crosssectional study among 300 Malaysian university students also showed similar findings when men tend to consume more industrial processed food that was high in sodium, compared to women who mainly obtained sodium from prepared food [14].

The concern was on the consumption of roti canai/ roti telur (flatbread) and fried noodles in men due to the high prevalence and high sodium from these foods. Rather than as a source of sodium, roti canai also contained high amount of fat from its main ingredient of

Table 4 Top 10 high sodium food most consumed by Malaysian adults by sex

\begin{tabular}{|c|c|c|c|c|c|}
\hline \multirow[t]{2}{*}{ Food items } & \multicolumn{2}{|l|}{ Male $(n=422)$} & \multirow[t]{2}{*}{ Food items } & \multicolumn{2}{|l|}{ Female $(n=610)$} \\
\hline & $\begin{array}{l}\text { Population consumed, } \\
\%(95 \% \mathrm{Cl})\end{array}$ & $\begin{array}{l}\text { mg sodium (per day), } \\
\text { median (IQR) }\end{array}$ & & $\begin{array}{l}\text { Population consumed, } \\
\%(95 \% \mathrm{Cl})\end{array}$ & $\begin{array}{l}\text { mg sodium (per day), } \\
\text { median (IQR) }\end{array}$ \\
\hline $\begin{array}{l}\text { White/whole } \\
\text { meal bread }\end{array}$ & $84.4(80.2,87.8)$ & $59.3(20.8,118.6)$ & Fried vegetable & $89.5(85.9,92.3)$ & $117.2(44.1,264.3)$ \\
\hline Fried vegetable & $83.2(77.8,87.5)$ & $88.1(33.0,231.3)$ & $\begin{array}{l}\text { White/whole } \\
\text { meal bread }\end{array}$ & $87.3(83.3,90.4)$ & $55.3(20.8,118.6)$ \\
\hline Omelet & $82.4(77.1,86.7)$ & $100.5(50.2,215.3)$ & Omelet & $78.1(73.3,82.3)$ & $71.8(33.5,215.3)$ \\
\hline $\begin{array}{l}\text { Fried chicken } \\
\text { with spices }\end{array}$ & $76.2(71.1,80.7)$ & $62.5(29.2,128.2)$ & Fried rice & $68.9(63.4,73.9)$ & $95.4(44.5,190.8)$ \\
\hline $\begin{array}{l}\text { Roti canai/roti } \\
\text { telur }\end{array}$ & $72.8(66.9,78.0)$ & $141.9(66.2,283.7)$ & $\begin{array}{l}\text { Fried chicken } \\
\text { with spices }\end{array}$ & $68.3(62.1,74.0)$ & $62.5(29.2,125.0)$ \\
\hline Fried rice & $71.2(65.4,76.4)$ & $95.4(44.5,190.8)$ & Nasi Lemak (set) & $65.2(58.8,71.0)$ & $88.0(29.3,125.7)$ \\
\hline Nasi Lemak (set) & $68.9(62.2,75.0)$ & $121.5(58.7,251.5)$ & Fried meehoon & $64.6(59.6,69.3)$ & $53.7(26.9,115.1)$ \\
\hline Fried noodle & $63.5(57.0,69.5)$ & $124.2(41.4,177.4)$ & Fried noodle & $59.2(52.3,65.8)$ & $82.8(41.4,177.4)$ \\
\hline Chicken curry & $60.2(54.5,65.6)$ & $13.5(4.5,20.3)$ & $\begin{array}{l}\text { Roti canai/roti } \\
\text { telur }\end{array}$ & $57.2(51.5,62.8)$ & $66.2(33.1,141.9)$ \\
\hline Fried meehoon & $58.6(51.0,65.7)$ & $53.7(26.9,115.1)$ & Chicken soup & $56.0(49.7,62.0)$ & $36.4(13.6,81.6)$ \\
\hline
\end{tabular}


Table 5 Top 10 food sources (food item) with the highest sodium consumption among Malaysian adults

\begin{tabular}{|c|c|c|c|c|c|}
\hline No. & Food items & $\begin{array}{l}\text { Unweighted } \\
\text { count }\end{array}$ & $\begin{array}{l}\text { Estimated } \\
\text { population }\end{array}$ & $\begin{array}{l}\text { Population consumed, \% } \\
(95 \% \mathrm{Cl})\end{array}$ & $\begin{array}{l}\text { mg sodium (per day), median } \\
\text { (IQR) }\end{array}$ \\
\hline 1 & Kolok mee/kampua mee & 118 & $1,749,135$ & $9.0(6.2,13.0)$ & $256.5(171.0,366.4)$ \\
\hline 2 & Light soy sauce & 351 & $6,443,736$ & $33.2(29.0,37.7)$ & $248.1(88.6,630.4)$ \\
\hline 3 & Curry noodle & 155 & $3,584,403$ & $18.5(14.4,23.3)$ & $164.2(82.1,246.4)$ \\
\hline 4 & $\begin{array}{l}\text { Vegetable with soy sauce/oyster } \\
\text { sauce }\end{array}$ & 260 & $5,234,602$ & $27.0(23.3,30.9)$ & $154.9(51.6,387.3)$ \\
\hline 5 & Fried instant noodle & 186 & $3,754,633$ & $19.3(15.6,23.8)$ & $122.3(61.2,244.6)$ \\
\hline 6 & Noodle soup & 299 & $5,537,271$ & $28.5(24.8,32.6)$ & $103.5(69.0,206.9)$ \\
\hline 7 & Vegetable cooked with salted fish & 161 & $3,469,039$ & $17.9(14.1,22.4)$ & $103.2(34.4,221.2)$ \\
\hline 8 & Fried vegetable & 870 & $16,775,456$ & $86.4(83.2,89.0)$ & $101.8(44.1,264.3)$ \\
\hline 9 & Roti canai/roti telur & 613 & $12,623,157$ & $65.0(60.7,69.1)$ & $99.3(66.2,283.7)$ \\
\hline 10 & Fried rice & 683 & $13,609,154$ & $70.1(65.8,74.0)$ & $95.4(44.5,190.8)$ \\
\hline
\end{tabular}

margarine, and it was also cooked with cooking oil [15]. A cross-sectional study in Malaysia also found overweight adults consumed more roti canai and fried noodles compared to their normal weight counterpart [16].

Kolok mee or kampua mee and light soy sauce appeared as the food most contributed to sodium consumption. Light soy sauce contributed the main source of sodium in food, as it was used as a condiment in most food preparation, including in mee kolok or kampua mee. There was a global overview of national programs to encourage food industries to reduce sodium in their products. The document also emphasized that products contributing to salt or sodium in the diet usually include sauces, particularly soy sauce and fish sauce in many Asian countries [17]. A local survey among university students also reported that majority of the students added salt/soy sauce to food and dipped food in soy sauce mixed with chopped chilies/garlic and/or sambal belacan [14].

Looking into those who consumed more or equal to $2000 \mathrm{mg}$ sodium per day, the preferred food is quite similar to the respondents who consumed sodium less than $2000 \mathrm{mg}$ per day. However, the quantity of intake played a major role. Respondents who consumed sodium more than $2000 \mathrm{mg}$ sodium per day ate large portions of fried vegetable, roti canai/roti telur, omelet, fried rice, and chicken curry compared to those who consumed less than $2000 \mathrm{mg}$ sodium. Personal initiative to cut off the quantity or portion of high sodium food that they consumed can be the best strategy to reduce sodium intake individually. However, in a community approach, reduction in salt intake can be achieved by a gradual and

Table 6 Top 10 food consumption by high sodium intake of $\geq 2000 \mathrm{mg} /$ day sodium and less than $<2000 \mathrm{mg} /$ day sodium

\begin{tabular}{|c|c|c|c|c|c|}
\hline \multirow[t]{2}{*}{ Food items } & \multicolumn{2}{|c|}{ High sodium intake ( $\geq 2000 \mathrm{mg} /$ day sodium) $(n=370)$} & \multirow[t]{2}{*}{ Food items } & \multicolumn{2}{|c|}{$\begin{array}{l}\text { Low sodium intake }(<2000 \mathrm{mg} / \text { day } \\
\text { sodium })(n=586)\end{array}$} \\
\hline & $\begin{array}{l}\% \text { consuming }(95 \% \\
\mathrm{Cl})\end{array}$ & $\begin{array}{l}\text { mg sodium (per day), median } \\
\text { (IQR) }\end{array}$ & & $\begin{array}{l}\% \text { Consuming } \\
(95 \% \mathrm{Cl})\end{array}$ & $\begin{array}{l}\text { mg sodium (per } \\
\text { day), } \\
\text { median(IQR) }\end{array}$ \\
\hline Fried vegetable & $87.5(83.7,90.4)$ & $115.7(44.0,246.72)$ & $\begin{array}{l}\text { White/whole meal } \\
\text { bread }\end{array}$ & $87.3(81.9,91.2)$ & $59.3(29.6,133.4)$ \\
\hline $\begin{array}{l}\text { White/whole meal } \\
\text { bread }\end{array}$ & $85.0(81.2,88.1)$ & $59.3(29.6,118.6)$ & Fried vegetable & $81.7(75.7,86.5)$ & $88.6(44.1,264.3)$ \\
\hline Omelet & $82.5(78.7,85.8)$ & $100.5(50.2,215.3)$ & Omelet & $75.8(68.2,82.1)$ & $71.8(33.5,213.3)$ \\
\hline $\begin{array}{l}\text { Fried chicken with } \\
\text { spices }\end{array}$ & $71.7(67.3,75.7)$ & $62.5(29.2,131.3)$ & $\begin{array}{l}\text { Fried chicken with } \\
\text { spices }\end{array}$ & $72.0(65.2,77.9)$ & $62.5(29.2,125.0)$ \\
\hline Fried rice & $69.1(63.1,74.5)$ & $95.4(44.5,278.3)$ & Fried rice & $71.5(65.1,77.1)$ & $66.8(33.4,143.1)$ \\
\hline Nasi Lemak (set) & $68.4(63.2,73.1)$ & $88.0(58.7,251.5)$ & Roti canai/roti telur & $67.8(61.4,73.6)$ & $66.2(33.1,141.9)$ \\
\hline Roti canai/ roti telur & $65.2(60.0,70.0)$ & $141.9(66.2,283.7)$ & Nasi Lemak (set) & $67.2(59.4,74.1)$ & $88.0(29.3,188.8)$ \\
\hline Fried meehoon & $61.9(54.5,68.9)$ & $53.7(26.9,115.1)$ & Fried noodle & $64.2(56.8,71.0)$ & $82.8(41.4,177.4)$ \\
\hline Fried noodle & $60.0(53.0,66.6)$ & $82.8(41.4,177.4)$ & Fried meehoon & $61.5(55.4,67.3)$ & $53.6(26.8,107.4)$ \\
\hline Chicken curry & $57.3(51.4,63.0)$ & $13.5(4.5,19.3)$ & Chicken curry & $56.5(49.5,63.2)$ & $9.0(4.5,19.3)$ \\
\hline
\end{tabular}


sustained reduction in the amount of sodium added to foods by the food industries $[18,19]$.

\section{Conclusion}

There are several aspects to highlight when describing patterns of high sodium food consumption among Malaysian adults. First, is the high sodium food choice, where almost similar food items were in the list of top ten. Second, is the method of preparation when most Malaysian adults obtained sodium from cooking or preparation of food. Third, is the amount of food consumed where it directly influence the sodium consumption. Therefore, an effective campaign targeting individual approach, community and also food industry is needed to prevent excessive sodium intake that linked to increased risk of hypertension and cardiovascular diseases.

\section{Abbreviations}

MyCoSS: Malaysian Community Salt Study; WHO: World Health Organization; RNI: Recommended Nutrient Intake; FFQ: Food Frequency Questionnaire; INTERMAP: International Study of Macro-and Micro-Nutrients

\section{Acknowledgements}

The authors would like to acknowledge the Director General of Health Malaysia for permission to publish this paper. Appreciation goes to the Department of Statistics, Malaysia, in the sampling process. Acknowledgment also goes to the Ministry of Health Malaysia (Nutrition Division, NonCommunicable Disease Section, State Health Departments, Liaison Officers, and Scouts) in the preparation and during the data collection. Our sincere appreciation also goes to all respondents and data collectors.

\section{About this supplement}

This article has been published as part of Journal of Health, Population and Nutrition Volume 40 Supplement 1, 2021: Malaysian Community Salt Survey 2017-2018 (MyCOSS). The full contents of the supplement are available online at https://jhpn.biomedcentral.com/articles/supplements/volume-40supplement-1.

\section{Authors' contributions}

$\mathrm{FJH}, \mathrm{FO}, \mathrm{RS}$, and GMG were responsible for the concept and project development. FO supervised the project's progress. MHA, CSM, FO, and WNKWK performed the statistical analysis and drafted the manuscript. NSMN and TA contributed to the review and editing this manuscript. All authors have read and approved the final manuscript.

\section{Funding}

Publication costs are funded by the Newton-Ungku Omar Fund: United King dom - Malaysia Bilateral Health Research Collaboration for NonCommunicable Diseases with the grant number of MR/P012590/1 (joint funding from the Academy of Sciences Malaysia, Malaysian IndustryGovernment Group for High Technology, and the Medical Research Council, United Kingdom). The funders had no role in the study design, data collection, data analysis, data interpretation, or writing of the article.

\section{Availability of data and materials}

The datasets used and/or analyzed during the current study are available from the corresponding author on reasonable requests.

\section{Declarations}

\section{Ethics approval and consent to participate}

Ethical approvals for the study were obtained from the Medical Research Ethics Committee (MREC), Ministry of Health Malaysia (NMRR-17-423-34969), and Queen Mary (University of London) Research Ethics Committee (QMER C2017/14) prior to conducting the study. Informed written consent was collected from all respondents at the beginning of the study.
Consent for publication

Not applicable.

\section{Competing interests}

The authors declare that they have no competing interests.

\section{Author details}

${ }^{1}$ Institute for Public Health, National Institutes of Health, Ministry of Health Malaysia, Setia Alam, Selangor, Malaysia. ${ }^{2}$ Wolfson Institute of Preventive Medicine, Barts and The London School of Medicine and Dentistry, Queen Mary University of London, London, UK. 3Policy and Strategic Planning Section, Allied Health Science Division, Ministry of Health Malaysia, Putrajaya, Malaysia.

Published: 31 May 2021

\section{References}

1. Germann, William J, Cindy L. Stanfield. Principles of human physiology. Vol. 1. Benjamin Cummings. 2002. https://doi.org/10.1078/0940-2993-00224.

2. Mozaffarian D, Fahimi S, Singh GM, Micha R, Khatibzadeh S, Engell RE, Lim S, Danaei G, Ezzati M, Powles J. Global sodium consumption and death from cardiovascular causes. New Engl J Med. 2014;371(7):624-34. https://doi.org/1 $0.1056 /$ NEJMoa1304127

3. Ma Y, He FJ, MacGregor GA. High salt intake: independent risk factor for obesity? Hypertension. 2015:66(4):843-9. https://doi.org/10.1161/ HYPERTENSIONAHA.115.05948.

4. Institute for Public Health. National Health \& Morbidity Survey (NHMS) 2015. Technical Report Vol. 2. Institute for Public Health, Jalan Bangsar Kuala Lumpur. 2015.

5. Appel LJ, Brands MW, Daniels SR, Karanja N, Elmer PJ, Sacks FM. Dietary approaches to prevent and treat hypertension: a scientific statement from the American Heart Association. Hypertension. 2006;47(2):296-308. https:// doi.org/10.1161/01.HYP.0000202568.01167.B6.

6. World Health Organization. Prevention of cardiovascular disease: guidelines for assessment and management of cardiovascular risk. Geneva: World Health Organization; 2007

7. Recommended Nutrient Intake (RNI) for Malaysia 2017. A report of the technical working group on nutritional guidelines. In: National Coordinating Committee on Food \& Nutrition: Ministry of Health Malaysia; 2017.

8. Institute for Public Health, Ministry of Health Malaysia. Determination of dietary sodium intake among the Ministry of Health Staff (MySalt 2015). Institute for Public Health: Ministry of Health Malaysia; 2015.

9. Institute for Public Health. Malaysian Adults Nutrition Survey (MANS) 2014, Vol.I: Methodology \& General Finding. In: Institute for Public Health: Ministry of Health Malaysia; 2014

10. Bhat R, Liong MT, Abdorreza MN, Karim AA. Evaluation of free radical scavenging activity and antioxidant potential of a few popular green leafy vegetables of Malaysia. Int J Food Properties. 2013;16(6):1371-9. https://doi. org/10.1080/10942912.2011.584202.

11. Institute for Public Health. Malaysian Adults Nutrition Survey (MANS) 2014, Vol.III : Food Consumption Statistics. In: Institute for Public Health: Ministry of Health Malaysia; 2014

12. Anderson CAM, Appel LJ, Okuda N, Brown IJ, Chan Q, Zhao L, Ueshima H, et al. Dietary sources of sodium in China, Japan, the United Kingdom, and the United States, women and men aged 40 to 59 years: the INTERMAP study. J Am Dietetic Assoc. 2010;110(5):736-45. https://doi.org/10.1016/j.ja da.2010.02.007.

13. Kearney J. Food consumption trends and drivers. Philos Trans R Soc Lond B Biol Sci. 2010;365(1554):2793-807. https://doi.org/10.1098/rstb.2010.0149.

14. Choong SSY, Balan SN, Chua LS, Say YH. Preference and intake frequency of high sodium foods and dishes and their correlations with anthropometric measurements among Malaysian subjects. Nutr Res Pract. 2012;6(3):238-45. https://doi.org/10.4162/nrp.2012.6.3.238

15. Badari SAZ, Arcot J, Sulaiman N. Food consumption patterns of lowerincome households in rural areas of Peninsular Malaysia. Jurnal Pengguna Malaysia. 2013;21:122-41.

16. Boo NY, Chia GJQ, Wong LC, Chew RM, Chong W, Loo RCN. The prevalence of obesity among clinical students in a Malaysian medical school. Singapore Med J. 2010;51(2):126 
17. Webster J, Trieu K, Dunford E, Hawkes C. Target salt 2025: a global overview of national programs to encourage the food industry to reduce salt in foods. Nutrients. 2014;6(8):3274-87.

18. Trieu K, Neal B, Hawkes C, Dunford E, Campbell N, Rodriquez-Fernandez R, Legetic B, McLaren L, Barberio A, Webster J. Salt reduction initiatives around the world-a systematic review of progress towards the global target. PloS one. 2015;10(7):e0130247.

19. He FJ, MacGregor GA. Reducing population salt intake worldwide: from evidence to implementation. Progress Cardiovasc Dis. 2010;52(5):363-82. https://doi.org/10.1016/j.pcad.2009.12.006.

\section{Publisher's Note}

Springer Nature remains neutral with regard to jurisdictional claims in published maps and institutional affiliations.

Ready to submit your research? Choose BMC and benefit from:

- fast, convenient online submission

- thorough peer review by experienced researchers in your field

- rapid publication on acceptance

- support for research data, including large and complex data types

- gold Open Access which fosters wider collaboration and increased citations

- maximum visibility for your research: over $100 \mathrm{M}$ website views per year

At $\mathrm{BMC}$, research is always in progress.

Learn more biomedcentral.com/submissions 